\title{
Consistent Maintenance Management Model: Results of Changes of Maintenance Organisation Structure and Processes
}

\author{
Jan Sailer ${ }^{1}$, Tomáš Hladík ${ }^{2}$ \\ ${ }^{1}$ Czech University of Life Sciences, Czech Republic, E-mail: Jan.Sailer@unipetrol.cz \\ ${ }^{2}$ Faculty of Engineering, Czech University of Life Sciences Prague, Czech Republic, E-mail: hladik@tf.czu.cz, hla- \\ dik@logio.cz
}

Number of asset management models, methodologies and tools are available and well known today. However, companies in industry adopt various organizational approaches to the asset management processes. This paper summarizes several examples of maintenance process models and presents a comparison of examples (benchmark) of real maintenance organizational structures. Used examples originate from chemical, petrochemical and automotive industries. On this background, a case study of major maintenance organization change in Unipetrol, a central-european refinery and petrochemical group (part of PKN Orlen), is presented and analysed. The goal of the implemented changes in the company was to increase the overall efficiency of the maintenance organization, mainly in the areas of management, and to achieve the set KPIs. Organizational changes were implemented on the base of the model of a close connection between maintenance and production organizations in the form of a Multiprofession production team, named "Facility team".

Changes in the organisational structure and asset management processes described in the paper had finally a significant impact on the number of management positions (reduction by $25 \%$ ), roles, competences and the asset management process flow. Regarding the quantitative impacts to KPIs in areas fulfilment of process safety requirements and efficiency after implementation of these changes, we notices a positive effect in the horizon of the coming year and the impacts are also evaluated and analyzed in the paper.

Keywords: Maintenance organization, Facility team, Maintenance KPI, Maintenance management

\section{Introduction}

Currently there are several asset management methodologies and tools available [1]. Even though the term Asset Management is defined through a set of national and global norms [2,3], in the vast majority of practical cases we see isolated processes and methodologies; even though these are efficient as far as their application and outputs are concerned, they mostly focus only on a single area or sub-process and are not interlinked, they do not form any consistent whole or do not respect the needs or organizational structure of the production plant $[4,5]$. This state is usually caused by the isolated development of individual methodologies, which are often commercial products. The time plays also an important role, since individual methodologies and tools were developed in a certain time frame and thus they logically cannot follow up on each other. For example the set of methodologies generally called Risk Reliability Management includes the Reliability Centered Maintenance, Risk Base Inspection and SIFpro ${ }^{C}[6]$ methodologies, whose goals are to generate optimized plans for preventive maintenance based on risk assessment. Individual methodologies generate plans for preventive maintenance but these plans ar in different formats, completely unsuitable for automated or batch transfer to central planning maintenance systems, where data are further processed within the planning and work implementation sub-process.

A frequent representative of such Central Maintenance Management System (CMMS) is SAP - the preventive maintenance administration module $[7,8$, 9]. Another factor which reduces the efficient implementation of modern methodologies for asset management is their low adaptability to the organizational structure of the production plant. The imperfect connection of asset management with the production area and with processes supporting the asset management process (such as the purchase of spare parts and consumable material, investments, safety and security, or HR) then leads to imperfect communication flows that reduce the organization's efficiency and lead to suboptimal asset management costs, reduced availability of production equipment and lower process safety. This could lead, for instance, to imperfect fulfilment of valid legislation requirements, incorrect usage of residual service life of production equipment or low coverage by predictive maintenance.

The facts specified above force us to view the asset 
management process as a consistent unit, integrated within the organizational structure of the production plant in a manner allowing efficient communication and goal sharing [10], whereas the real needs of the production facility, the medium- and long-term plans as well as the mission and vision of the company all need to be respected $[11,12]$.

The goal of the proposed solution spans all parts of the asset management process, from entering requests, their approval and prioritization, system of technical preparation of a job, optimal planning, transfer for implementation, feedback on implementation and final acceptance and closure of a job, whereas emphasis is placed on efficient communication, work quality and utilization of work capacities $[13,14,15]$. Organizationally, it is necessary to setup the process in a way that will ensure that individual decision steps will be carried out on the operator's side and not on the maintenance's side. On one hand, this results in an independent approval process with respect to costs management, and on the other this leads to clearly defined priorities by the operator, who is then forced to make decisions not only based on the current operating situation but also based on the costs and indicators for long-term operational availability [16]. As was mentioned earlier, one of the primary tools to achieve optimal decision-making was sharing of goals within key indicator assessment for processes, whereas the operator shares maintenance goals such as maintenance costs, mechanical availability of devices, mean time between failures (MTBF) and/or efficiency of the maintnance work implementor. On the other hand, the maintenance side shares operational goals, such as operational availability, use of production facilities, energy index, or for instance variable costs [17]. From an organizational standpoint, the solution is based on the structure of a so-called multi-professional team, where a single organizational element has representatives of all key areas required for efficient administration and management of the entrusted production section. In practice, this means that the team includes representatives of production, technology and maintenance, as well as other areas such as reliability and quality management who are responsible for the efficiency of central specialized bodies in given areas. The implementation of a multi-profession team into the organization of maintenance and operation has become the main goal of changes in terms of process settings.

One of the key areas that need to be emphasized is the definition of process efficiency indicators for individual management levels, including the definition of key indicators [16]. This set of indicators contains not only basic items such as the aforementioned fixed costs for maintenance, MTBF, or mechanical availability of equipment, but also indicators monitoring process safety of equipment such as Loss of Primary Containment (LOPC), number of process alarms per time unit, success rate of diagnostics of rotary machines etc.

Tab. 1Master list of harmonized indicators [18, 19, 20, 21, 22, 29]

\begin{tabular}{|c|c|c|c|c|c|c|c|}
\hline \multicolumn{2}{|r|}{ EN 15341} & \multicolumn{2}{|r|}{ SMRP } & \multicolumn{2}{|r|}{ EN 15341} & \multicolumn{2}{|r|}{ SMRP } \\
\hline $\begin{array}{c}\text { Indicator } \\
\text { No }\end{array}$ & Indicator Ratio & $\begin{array}{c}\text { Metric } \\
\text { No }\end{array}$ & Metric name & \begin{tabular}{|c|} 
Indicator \\
No
\end{tabular} & Indicator Ratio & \begin{tabular}{|c|} 
Metric \\
No
\end{tabular} & Metric name \\
\hline E1 & $\begin{array}{l}\text { Total Maintenance Cost x100/ } \\
\text { Assets Replacement Value }\end{array}$ & 1.5 & $\begin{array}{c}\text { Annual Maintenance Cost } \\
\text { as a percent of RAV }\end{array}$ & T18 & $\begin{array}{c}\text { Number of Systems Covered by Criticality } \\
\text { Analysis } \times 100 / \\
\text { Total Number of Systems }\end{array}$ & 3.1 & $\begin{array}{l}\text { Systems Covered } \\
\text { by Criticality } \\
\text { Analysis }\end{array}$ \\
\hline E3 & $\begin{array}{l}\text { Total Maintenance Cost / } \\
\text { Quantity of output }\end{array}$ & 1.3 & Maintenance Unit Cost & T21 & Total Time o restore $\mathrm{x} 100 /$ & 352 & MTTR \\
\hline \multirow[b]{2}{*}{ E7 } & \multirow{2}{*}{$\begin{array}{c}\text { Average inventory value of maintenance } \\
\text { materials } \times 100 / \\
\text { Asset Replacement Value }\end{array}$} & \multirow[b]{2}{*}{1.4} & \multirow{2}{*}{$\begin{array}{c}\text { Stocked MRO Inventory } \\
\text { Value As s Percent of } \\
\text { RAV }\end{array}$} & 121 & $\begin{array}{c}\text { Number of failures } \\
\end{array}$ & 0.0 .2 & Direct tolndirect \\
\hline & & & & $\mathrm{O} 3$ & $\begin{array}{c}\text { Number of inidirect maintenance personnel } \\
x 100 / \\
\text { Number of direct maintenance personnel }\end{array}$ & 5.5 .3 & $\begin{array}{l}\text { Direct to Indirect } \\
\text { Maintenance } \\
\text { Personnel Ratio }\end{array}$ \\
\hline E8 & $\begin{array}{c}\text { Total internal personnel cost spent in } \\
\text { Maintenance } x 100 / \\
\text { Total Maintenance Cost Value }\end{array}$ & 5.5 .5 . & $\begin{array}{l}\text { Internal Maintenance } \\
\text { Emplyee Cost }\end{array}$ & 08 & $\begin{array}{c}\text { Man-hours used for continuous } \\
\text { improvement x100 / Total maintenance } \\
\text { personnel man-hours }\end{array}$ & 5.7 .1 & $\begin{array}{l}\text { Continous } \\
\text { Improvement Hours }\end{array}$ \\
\hline E10 & $\begin{array}{l}\text { Total contractor cost } \times 100 / \\
\text { Total maintenance cost }\end{array}$ & 5.5 .71 & Contractor Cost & 010 & Direct maintenance personnel on shift $\times 100 /$ & 5.56 & on \\
\hline \multirow{2}{*}{ E11 } & \multirow{2}{*}{$\begin{array}{c}\text { Total cost of maintenance materials x } 100 / \\
\text { Total Maintenance Cost }\end{array}$} & \multirow{2}{*}{5.5 .38} & \multirow{2}{*}{$\begin{array}{l}\text { Maintenance Material } \\
\text { Cost }\end{array}$} & & & & \\
\hline & & & & O16 & $\begin{array}{l}\text { Corrective maintenance man-hours x } 100 / \\
\text { Direct maintenance man-hours }\end{array}$ & 5.1 .2 & $\begin{array}{c}\text { Corrective } \\
\text { Maintenance Hours }\end{array}$ \\
\hline E12 & $\begin{array}{c}\text { Total cost of maintenance materials } \times 100 / \\
\text { Average inventory value of Maintenace } \\
\text { materials } \\
\text { Warehouse turnover }\end{array}$ & 5.5 .31 & Stores Inventory Turns & 017 & $\begin{array}{c}\text { Immediate Corrective maintenance man- } \\
\text { hours } \times 100 / \\
\text { Total maintenance man-hours }\end{array}$ & 5.4 .1 & Reactive Work \\
\hline E13 & $\begin{array}{c}\text { Cost for indirect maintenance personnel } \\
\text { x100 / } \\
\text { Total Maintenance Cost }\end{array}$ & 5.5 .4 & $\begin{array}{l}\text { Indirect Maintenance } \\
\text { Personnel Cost }\end{array}$ & 018 & $\begin{array}{c}\text { Preventive maintenance man-hours x100 / } \\
\text { Total maintenance man-hours }\end{array}$ & 5.4 .2 & Proactive Work \\
\hline E15 & $\begin{array}{c}\text { Total Maintenance Cost } \\
\text { Corrective maintenance cost x100 / } \\
\text { Total Maintenance Cost }\end{array}$ & 5.1 .1 & $\begin{array}{c}\text { Corrective Maintenance } \\
\text { Cost }\end{array}$ & 019 & $\begin{array}{c}\text { Condition based maintenance man-hours } \\
\times 100 / \text { I } \\
\text { Total maintenance man-hours }\end{array}$ & 5.1 .6 & $\begin{array}{c}\text { Condition Based } \\
\text { Maintenance Hours }\end{array}$ \\
\hline E17 & $\begin{array}{l}\text { Condition based maintenance cost / } \\
\text { Total Maintenance Cost }\end{array}$ & 5.1 .5 & $\begin{array}{l}\text { Condition Based } \\
\text { Maintenance Cost } \\
\end{array}$ & $\mathrm{O} 20$ & $\begin{array}{c}\text { Predetermined maintenance man-hours } \\
\times 100 / \\
\text { Total maintenance man-hours }\end{array}$ & 5.1 .4 & $\begin{array}{c}\text { Preventive } \\
\text { Maintenance Hours }\end{array}$ \\
\hline E18 & $\begin{array}{l}\text { Predetermined maintenance cost x } 100 \text { / } \\
\text { Total Maintenance Cost }\end{array}$ & 5.1 .3 & $\begin{array}{l}\text { Preventive Maintenance } \\
\text { Cost }\end{array}$ & & & & \\
\hline E20 & $\begin{array}{l}\text { Maintenance shutdown cost x100 / } \\
\text { Total Maintenance Cost }\end{array}$ & 5.1 .9 & $\begin{array}{l}\text { Maintenance Shutdown } \\
\text { Cost }\end{array}$ & $\mathrm{O} 21$ & $\begin{array}{c}\mathrm{x} 100 / \\
\text { Total internal maintenance man-hours } \\
\end{array}$ & 5.5 .8 & Maintenance Hours \\
\hline E21 & $\begin{array}{l}\text { Cost of training for maintenance } / \\
\text { Number of maintenance personnel }\end{array}$ & 4.2 .1 & $\begin{array}{l}\text { Maintenance Training } \\
\text { Cost }\end{array}$ & $\mathrm{O} 22$ & $\begin{array}{l}\text { Numbers of work orders performed as } \\
\text { scheduled } x 100 / \\
\text { Total number of scheduled work orders }\end{array}$ & 5.4 .4 & $\begin{array}{c}\text { Schedule } \\
\text { Compliance - Work } \\
\text { Orders }\end{array}$ \\
\hline T1 & \begin{tabular}{|c|} 
Total Operating time $\times 100 /$ \\
Total Operating time + Downtime due to \\
maintenance
\end{tabular} & 2.2 & Availability & $\mathrm{O} 23$ & $\begin{array}{c}\text { Number of maintenance internal personnel } \\
\text { man-hours for training x } 100 \text { / Total internal } \\
\text { maintenance man-hours }\end{array}$ & 4.2 .2 & $\begin{array}{l}\text { Maintenance } \\
\text { training hours }\end{array}$ \\
\hline $\mathrm{T} 2$ & $\begin{array}{l}\text { Achieved uptime during required time } \times 100 / \\
\text { Required time }\end{array}$ & 2.2 & Availability & & $\begin{array}{l}\text { Number of the spare parts supplied by the } \\
\text { warehouse as requested } x 100\end{array}$ & & \\
\hline T17 & $\begin{array}{l}\text { Total operating time } \times 100 / \\
\text { Number of failures }\end{array}$ & 3.5 .1 & MTBF & 026 & $\begin{array}{l}\text { Total number of spare parts required by } \\
\text { maintenance }\end{array}$ & 5.5 .33 & Stock outs \\
\hline
\end{tabular}


The structure of monitored indicators is based on a classical pyramid logic, where the number of monitored items becomes smaller in the direction towards top management $[15,23]$.

The primary contribution is the creation of an asset management model which will ensure improvement of mutual communication and coordination between individual company bodies [24], improvement of availability indicators for production equipment, optimization of costs for the implementation of maintenance activities, improvement of process safety indicators such as LOPC or number of process alarms. The author intends to demonstrate these improvements based on a real-life implementation of the proposed process solution.

For creation of such an asset management model, it is vital to reflect current problems and trends in maintenance organizational structures. There are two basic forms of maintenance organizational structures: decentralized (area) and centralized. In case of decentralized organization, work control is delegated to individual production areas. On the other hand, in central organization all work orders are controlled from a central shop. (Maynard, 2001) [26]. For smaller maintenance organizations it is typical to use central form, for larger organizations decentralized shop concept is widely used. Combination of both concepts (area central) might be used for multilevel maintenance, where specialists are assigned to specific areas, maintaining the key equipment. Skills which are not needed on a daily basis are ensured from the central shop when needed.
Organizational structure can be partly described by the maintenance organization ratio and ordinarily it is about 15:1. However this ratio must be set carefully with respect to the skills and daily agendas of supervi-sors, machine shop dispositions and to the form of production [25].

\section{Examples of maintenance process models and maintenance strategy development}

One of the main factors for the maintenance organization are the characteristics of the maintenance needs that are generated by the assets.

A possible scenario of a production plant for chemical products can serve as an example.

Originally all the repair works arising out of the maintenance needs (or demand) of the plant were undertaken by local maintenance department personnel. After a major decrease of $40 \%$ in production output due to lack of demand, it was decided by management to reduce the numbers of production and maintenance personnel. The further investigation resulted in two main options to choose between: either completely outsource the maintenance function, or outsource as much as possible. For practical reasons it was decided that a maximum of $50 \%$ of the work had to be done by maintenance department and $10 \%$ by operators undertaking first line maintenance work. So, $40 \%$ of all work was outsourced, in particular all work on building services installations and all the utility equipment. [26]. Scheme of possible organisation is presented on Fig. 1.

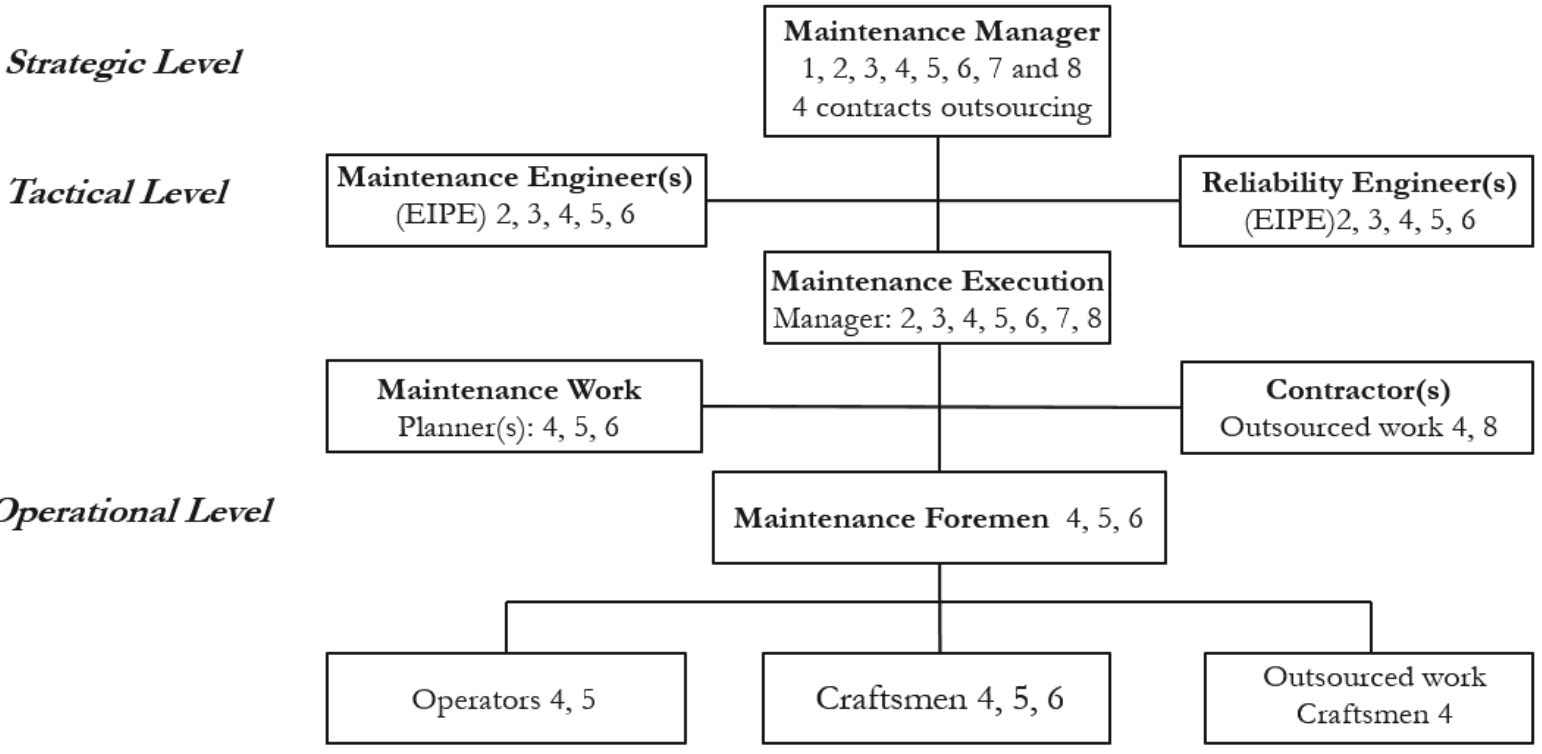

Fig. 1 Possible organization of the maintenance department for a production plant [26]

Another example of maintenance strategy development is provided by company which decided to create a maintenance model based on the centralized management, as shows Fig. 2. The model helps to avoid the chaos of diverse demands that can arise in maintenance from day to day. It provides guidance, organisation and sense of importance for the company. 


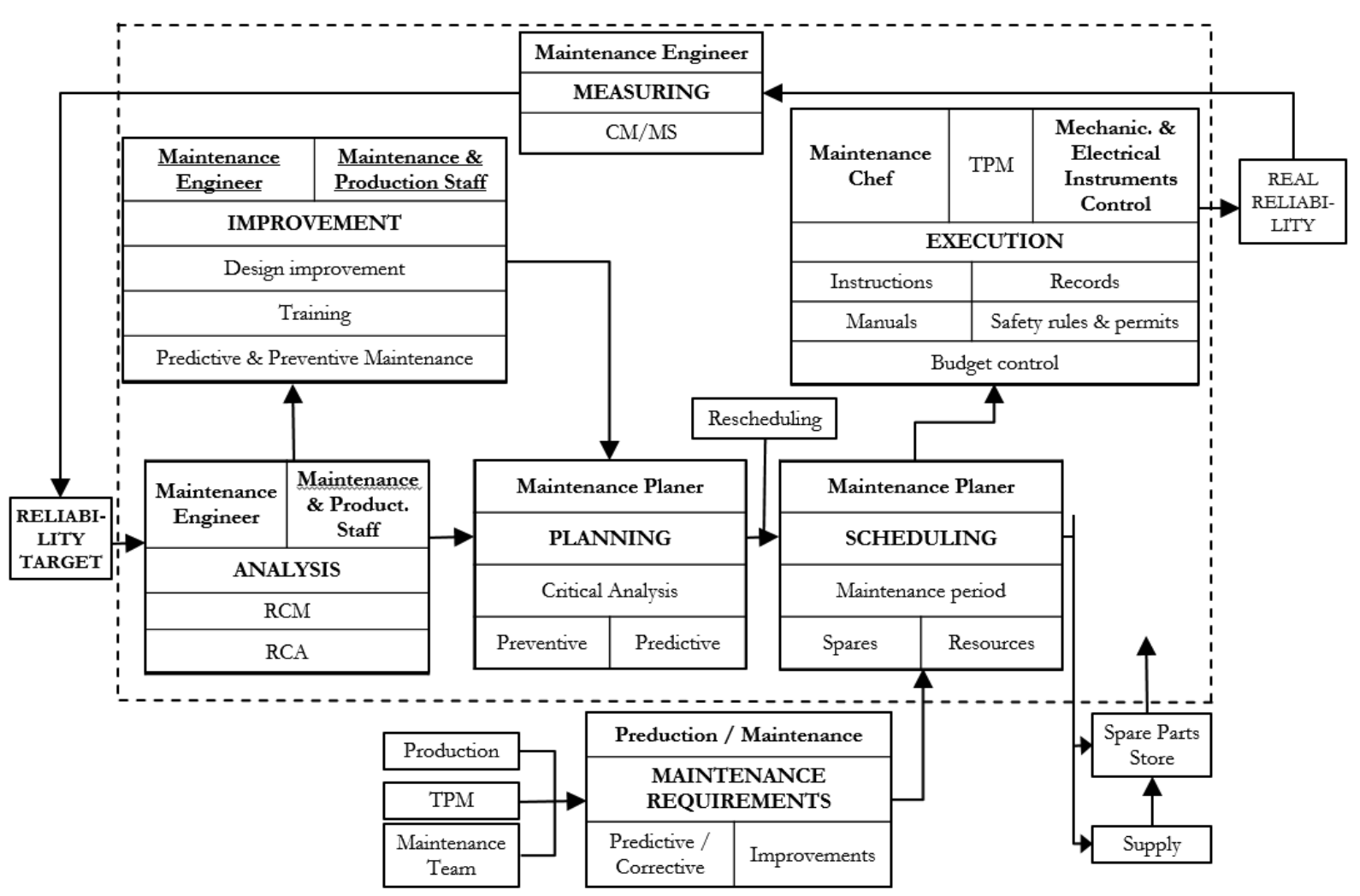

Fig. 2 Example of a maintenance strategy development [27]

Regardless of the organization formal structure and the position of maintenance within the structure, there exist certain generally accepted principles, see example on Fig. 3. Employees must know what they are responsible for and whom they report to. Managers are required to know who is responsible for setting goals and all other activities needed for their success. The organization structure represents these responsibilities in the simplest and obvious way. The organization structure is clearly perceived on the level where business policy is formulated in the organization, however, it is essential that the organization structure is clearly understood on the level of work execution too $[28,30]$.

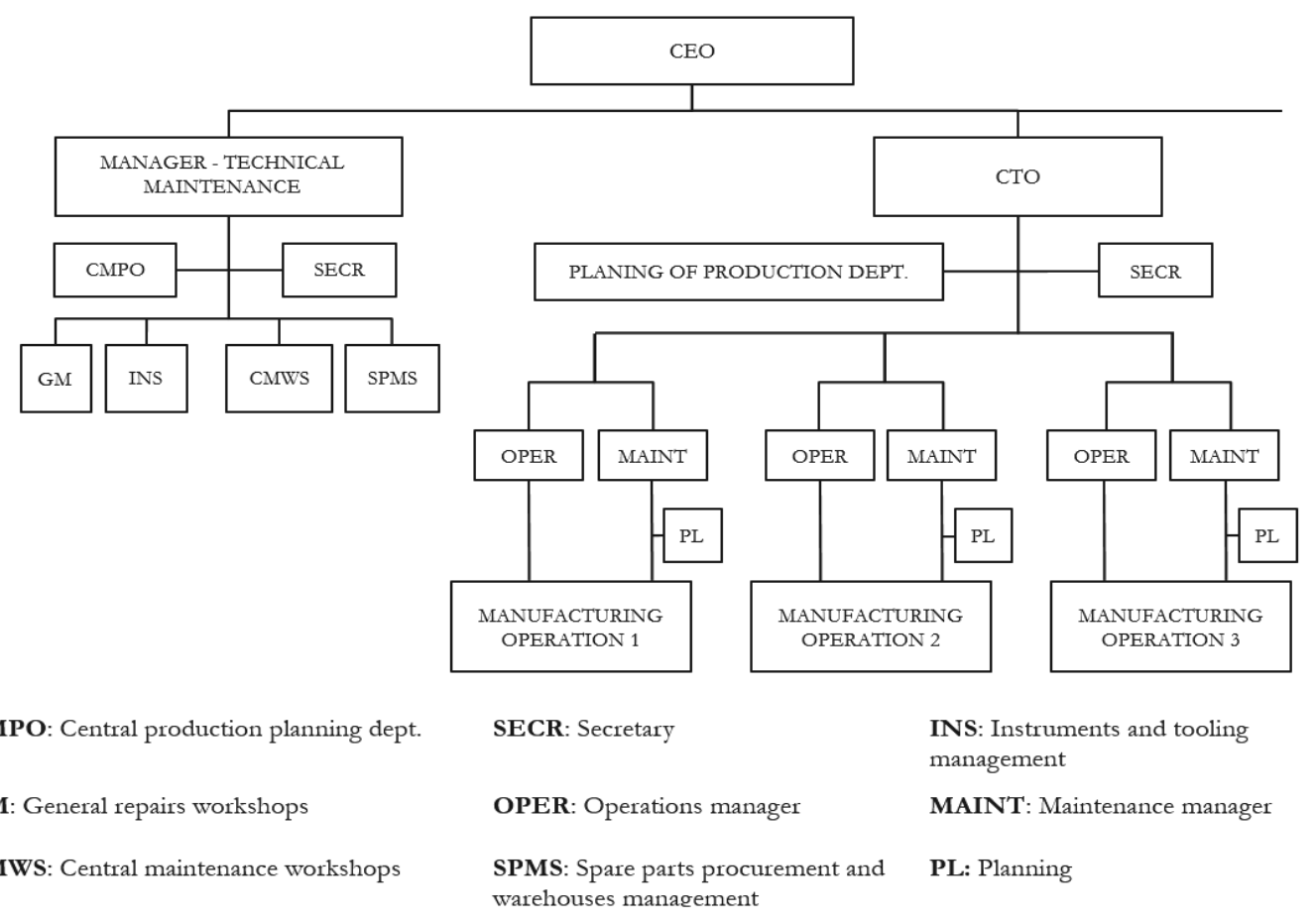

Fig. 3 Example of organization structure of combined maintenance [29] 


\section{Examples of real maintenance organizati- onal structures}

Useful tool for determination which organizational structure should be used, is benchmarking of maintenance structures. Basic benchmarking of 5 similar maintenance organizations in automotive industry was conducted for comparison. It should be considered, that organization structure is strongly affected by the level of outsourcing, scale of operation and technology type. This assumption was generally confirmed by the results of the benchmarking presented in following Tab. 2 and diagrams.

Tab. 2 Benchmarking of five similar maintenance organizations in automotive industry

\begin{tabular}{|l|c|c|c|c|c|}
\hline $\begin{array}{c}\text { Automotive industry } \\
\text { maintenance }\end{array}$ & Cars/day & \# shifts & $\begin{array}{c}\text { Total head- } \\
\text { count }\end{array}$ & $\begin{array}{c}\text { Level of outsour- } \\
\text { cing }\end{array}$ & $\begin{array}{c}\text { Manager/Staff } \\
\text { Ratio }\end{array}$ \\
\hline Assembly line A & 1000 & 2 & 42 & medium & $14.3 \%$ \\
\hline Assembly line B & 1500 & 3 & 50 & medium & $13.0 \%$ \\
\hline Assembly line C & 580 & 3 & 28 & high & $21.0 \%$ \\
\hline Bodyshop-welding & 1400 & $/$ & 48 & high & $12.5 \%$ \\
\hline Paintshop & 2000 & $/$ & 91 & medium & $13.2 \%$ \\
\hline
\end{tabular}

This table sums up the following graphics:

Automotive, Assembly line A

Production: 1000 cars/day, 2 shifts operation, Total headcount: 42, Level of maintenance outsourcing: medium

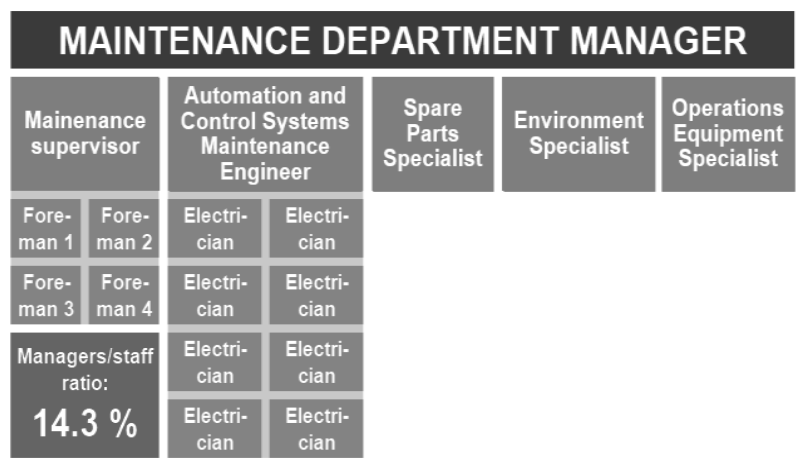

Automotive, Assembly line B

Production: 1500 cars/day, 3 shifts operation, Total headcount: 50, Level of maintenance outsourcing: medium

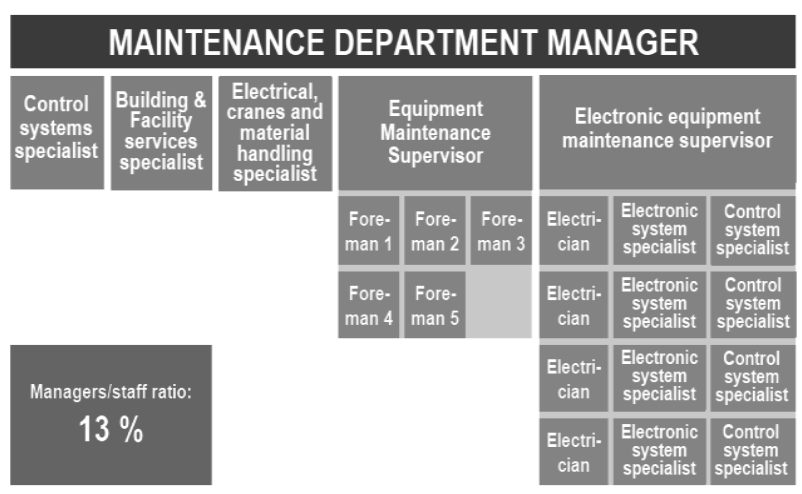

Automotive, Assembly line C

Production: 580 cars/day, 3 shifts operation, Total headcount: 28, Level of maintenance outsourcing: high

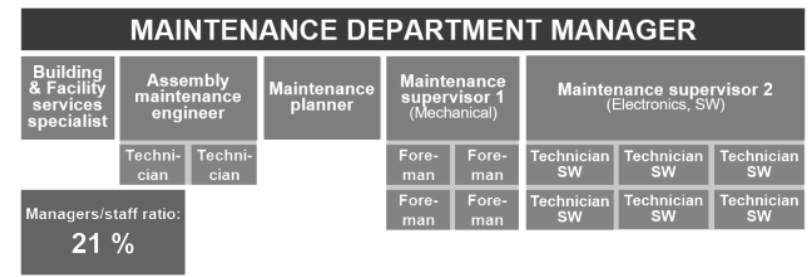

Automotive, Bodyshop - welding

Production: 1400 cars/day, Total headcount: 48, Level of maintenance outsourcing: high

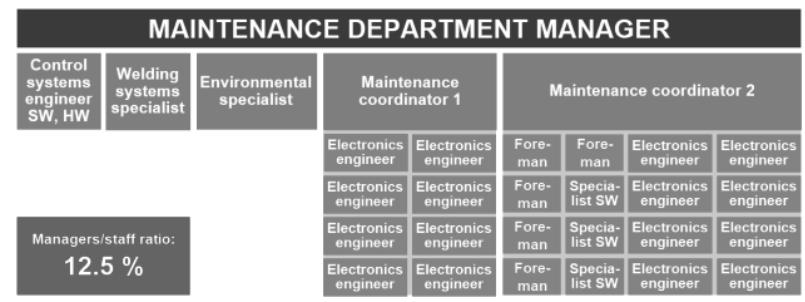

Automotive, Paintshop

Production: 2000 cars/day, Total headcount: 91, Level of maintenance outsourcing: medium

\section{MAINTENANCE DEPARTMENT MANAGER}

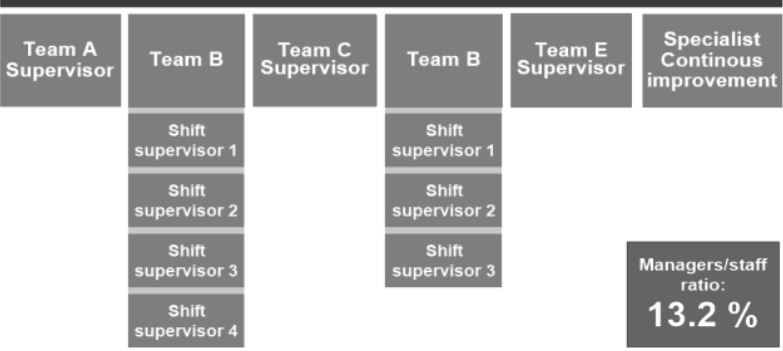

\section{Maintenance organization change in Unipetrol}

The decentralized (area) maintenance model was applied over a long period for individual production 
plants in Unipetrol in the past. It was during times when the company had its own in-house executive maintenance including workshops and machinery. Change occurred in the nineties, when the company underwent privatisation and almost all service activities were split off and further used in the outsourcing form. At that time, changes in the organisational structures of maintenance were also accelerated, it was necessary to adapt to a different model of operation. Over next fifteen years many changes occurred, when organisation of maintenance settled on the decentralized model with a specific small role played by centralised services which constituted the basic service for individual maintenance operations. The central part included technical diagnostics, cost reporting and basic administration of the maintenance process. No central technical engineering existed existed at that time as well as no system of uniform strategic management, for example in the field of reliability, inspection, risk management, planning and strategy for preventative maintenance. The interconnection with the field of production differed for various production units. This model of maintenance management required a large number of management employees and ensured only minimal option for unified management of maintenance strategy.

In 2014, the company decided to implement the organisational model of Facility Teams across the board for management in the field of production. This concerns a multi-professional team which is responsible for comprehensive management of a defined production unit and which also allows the close connection with organisation of maintenance.

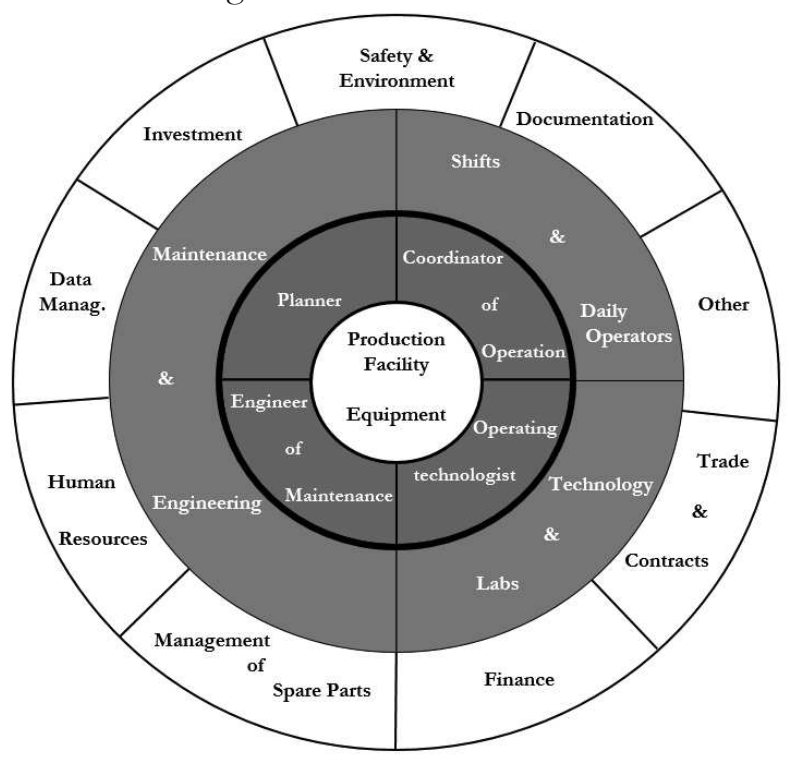

Fig. 4 Facility Team

Apart from the position of production technologist and energy technologist, the Facility Team is made up of a Reliability Engineer, Main Maintenance Engineer, Operations and Maintenance Coordinator and Scheduler Fig. 4. Thanks to these positions the close interconnection with organisation of maintenance and its suppliers is ensured.

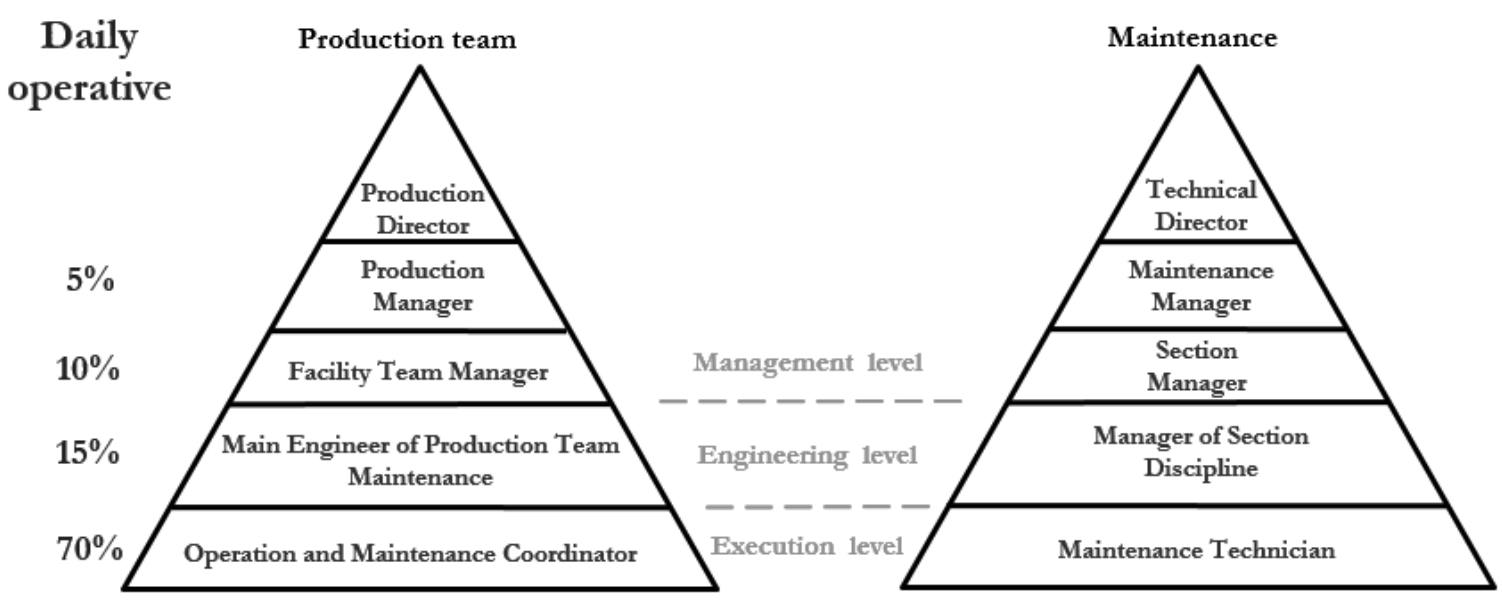

Fig. 5 Pyramid

In order to ensure that responsibilities and communication between in-house production and maintenance are clearly defined, transition to Facility Teams required a change in the organisational structure of maintenance Fig. 5. These changes were at the same time used to ensure more complex changes in organisation of in-house maintenance, whereas centralisation occurred in the executive part of maintenance and the level of technical engineering was created, allocated to departments according to technical expertise Fig. 6. 


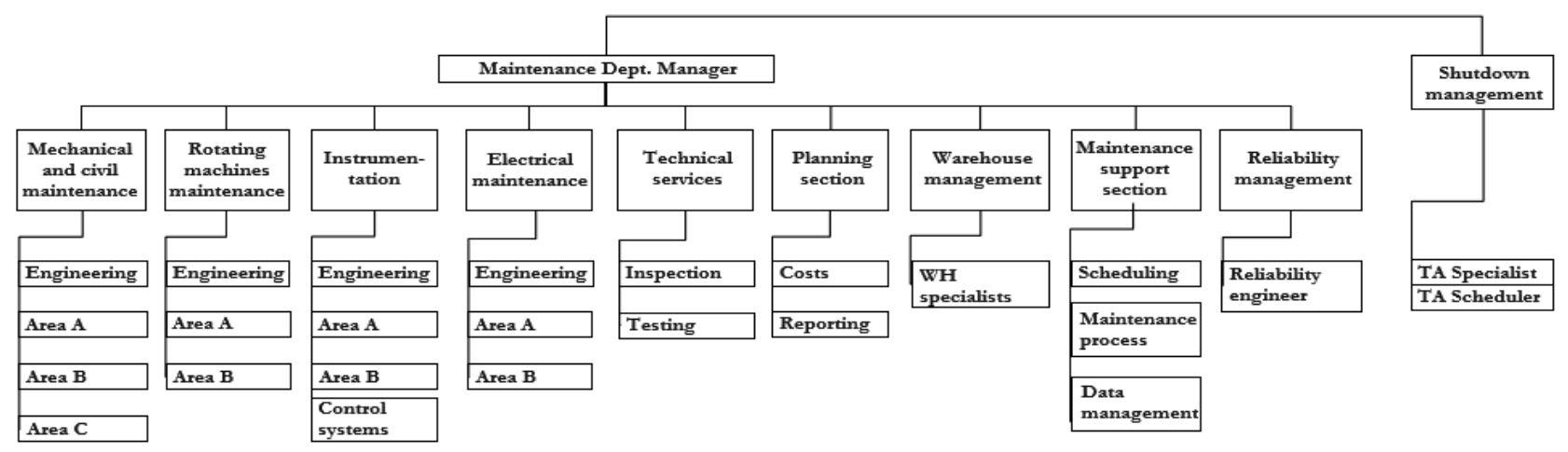

Fig. 6 Organisational chart

\section{Evaluation of the change-impact to KPIs}

Changes in the organisational structure described above had an impact on the number of employees in management positions, bringing a reduction in their number from 12 to 9 , i.e. by $25 \%$. However, the reason behind these organisational changes was not reduction of the number of jobs, but increase in the specialist abilities in the field of technical engineering and
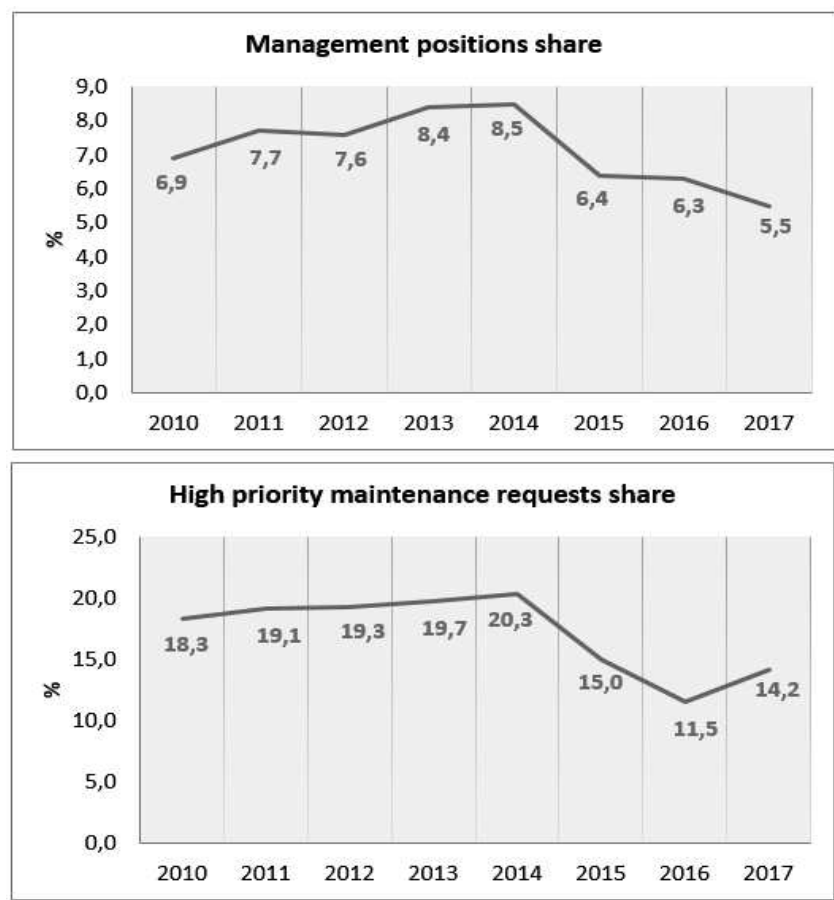

setup of organisation in such a way that competences and flow of information are clearly defined within the framework of interconnection between organisation of production and organisation of maintenance. Within one year from implementation in 2014, the implemented changes began to have a positive effect on the trends of key indicators of the process safety and planning effectivity, as can be seen on Fig. 7.
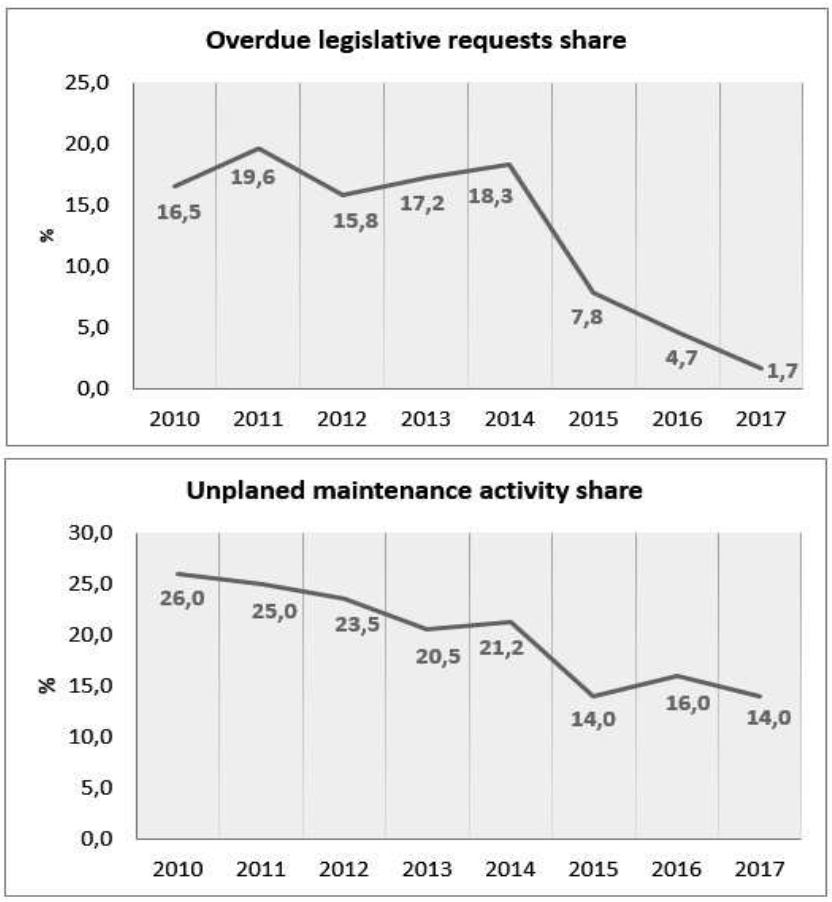

Fig. 7 Trends of maintenance KPIs after organisational change implementation in 201

\section{References}

[1] LEGÁT V. (2009). Asset management - moderní cesta k. lepšs údř̌bě a využiti majetku.

[2] ISO 55000 (2014). Overview, principles and terminology. International Organization for Standardization.

[3] ISO 55001 (2014). Management systems - Requirements, International Organization for Standardization.

[4] FLYNN B., SCHROEDER R., SAKAKIBARA S. (1995). The impact of quality management practices on performance and competitive advantage. Decision Sciences; 26(5): 659-692.

[5] TIONG K. L., ZAKUAN N., SAMAN M. Z. M. (2012). Quality Management Maintenance and Practices- Technical and Non-Technical Approaches. Procedia - Social and Behavioral Sciences 2012; 65(3): 688-696. Available at: http://ac.elscdn.com/S1877042812051701/1-s2.0-

S1877042812051701-main.pdf?_tid=cf5bafaae396-11e5-a6f7- 
00000aacb362\&acdnat $=1457267436 \_56 e 5753$ 0c80d71c58035678bdc3cd667

[6] Shell Global Solution International (2013). Introduction to Risk \& Reliability Management.

[7] MOURTZIS D., VLACHOU E., MILAS N., XANTHOPOULOS A. (2016). Cloud-based approach for maintenance of machine tools and equipment based on shop-floor monitoring. Procedia CIRP 2016; 41: 655-660. Available at: cdn.com/S2212827115011488/1-s2.0http://ac.elsS2212827115011488main.pdf?_tid=6955bd92-e399-11e5-88a700000aacb35e\&acdnat $=1457268554 \_a 110710$ 0a41388df23e56a2c03afbc1b

[8] TAN W., STEEL A., TOLEMAN M. (2009). Implementing IT service management: a case study focussing on critical success factors. Journal of Computer Information Systems; 50(2): 1-12.

[9] VALESKO S. (2010). CMMS increases efficiency, cuts downtime. The National Provisione; 224(3): 20-23.

[10] NENIČKOVÁ H. (2011). Critical success factors for ITIL best practices usage. Economics and Management, 16(1); 839-844.

[11] NEWIS M. (2005). M 380 - Maintenence Management MERIT. Shell Global Solution International.

[12] POLOUČEK J. (2013). Řízení změn procesů údržby.

[13] KUDA F., BERÁNKOVÁ E., SOUKUP P. (2012). Facility management in a nutshell for professionals and lay people. Olomouc: Form Solution. 978-80-905257-0-2

[14] LEGÁT V. (2009). Plánováni ₹̛drojũ v údry̌bee a jejich optimalizace.

[15] WIREMAN T. (2004). Benchmarking best practices in maintenance management. Industrial Press.

[16] ČSN EN 15341 (2010). Údr:̌ba - Klícové indikátory výkonnosti údržby. ÚNMZ.

[17] ABREU J., MATINS P. V., FERNANDES S., ZACARIAS M. (2013). Business Processes Improvement on Maintenance Management: Case Study. Procedia Technology 2013; 9: 320-330. Available at: http://ac.elscdn.com/S2212017313001904/1-s2.0-

S2212017313001904main.pdf?_tid=2a5502a6-e394-11e5-9a4f00000aab0f26\&acdnat=1457266301_f1 f8be8b 0840ac887f5676c1ad08ebe9
[18] ČSN EN: 15341 (2007). Maintenance Key Performance Indicators.

[19] EFNMS Working Group 7 (2002) Benchmarking Definitions and Indicators.

[20] KAHN J., SVANTESSON T. (2012). Maintenance and Reliability Indicator Harmonization Project. EFNMS and SMRP.

[21] KAHN J., SVANTESSON T., OLIVER R., SANTINI F. (2008). Global Maintenance and Reliability Indicators - Fitting the Pieces Together, 1st edition, EFNMS and SMRP.

[22] WILSON A. (2013). Asset Management, focusing on developing maintenance strategies and improving performance. Conference Сотmunication; pp 162.

[23] YOUNUS J., FAHAD M., KHAN M. A. (2016). Evaluation and benchmarking of maintenance organization and planning/scheduling at automotive industries of Pakistan. Procedia CIRP 2016; 40: 712-716. Available at: http:/ /ac.els-

cdn.com/S2212827116001748/1-s2.0-

S2212827116001748-main.pdf?_tid=9faa4610e3a8-11e5-8224-

00000aab0f6b\&acdnat $=1457275087$ d2820f8

5144a16a2a7f5c59102e4b262

[24] MARCIANO P. (2013). Cukr a bič nefunguji.

[25] MAYNARD H. Z. (2001). Maynard's industrial engineering handbook. McGraw-Hill Professional. pp 2248-2250.

[26] ZAAL T. (2011). Profit-Driven Maintenance for Physical Assets. Maj Engineering Publishing. pp 216-220.

[27] WILSON A. (2013). Asset Management, focusing on developing maintenance strategies and improving performance. Conference Communication; pp 621-623.

[28] LEGÁT V. a kol. (2013). Management a inženýrství údržby. Professional Publishing, Pp 51-57.

[29] TERINGL A., ALEŠ Z., LEGÁT V. (2015). Dependability Characteristic - Indicators for Maintenance, Performance Measurement of Manufacturing Technology, Manufacturing Technology Engineering Science and Research Journal, Vol. 15, ISSN 1213-2489.

[30] LEGÁT V., ALEŠ Z., HLADÍK T. (2017). Maintenance Audit: the Tool for Maintenance Management Quality of Manufacturing Equipment, Manufacturing Technology Engineering Science and Research Journal, Vol. 17, ISSN 1213-2489. 